Jurnal Ilmu Dan Teknologi Kesehatan

Vol 7, No 1, September 2019,

ISSN: 2338-9095 (Print)

ISSN: 2338-9109 (online)

\title{
Effect of Health Education Demonstration Method and Leaflet Media about Consciousness on Knowledge and Attitude of Hormonal KB Acceptors
}

\author{
Sri Mulyati, Winancy \\ Poltekkes Kemenkes Jakarta III \\ Email: winancygunawan@gmail.com
}

\begin{abstract}
Artikel history
Dikirim, Jul $4^{\text {th }}, 2019$

Ditinjau, Agust $4^{\text {th }}, 2019$

Diterima, Sept $5^{\text {th }}, 2019$
\end{abstract}

\begin{abstract}
Breast cancer is a disease with characterized by uncontrolled development of cells and breast tissue. Women who has to use acceptors Hormonal contraception (Hormonal KB) has a risk of developing breast cancer. Self Breast Examination (BSE) or Periksa Payudara Sendiri (SADARI) is one of the easier and more efficient ways to be able to detect breast abnormalities by yourself. The purpose of the study was to determine the effect of health education by demonstration methods and leaflet media on breast self-examination of the knowledge and attitudes of WUS hormonal family planning acceptors about SADARI. This study was a quasi experiment: pretest-posttest design. The population was divided into 3 groups, namely groups given health education with leaflets, with demonstration methods, and a combination of leaflets + demonstrations. The results showed that the knowledge and attitudes of respondents before and after health education with leaflet media, demonstration methods, and leaflet + demonstration media combinations experienced a significant increase with a value of $p<0.05(p=0,000)$. The increase score in the value of the average rating of knowledge was statistically significant in the demonstration group better than the leaflet group. The difference in the average value of the demonstration and demonstration group rankings + leaflets is not meaningful.
\end{abstract}

Keywords: Breast Cancer; Women of childbearing age; Hormonal KB acceptors

\begin{abstract}
ABSTRAK
Kanker payudara adalah penyakit yang ditandai dengan perkembangan sel dan jaringan payudara yang tidak terkontrol. Wanita yang harus menggunakan akseptor kontrasepsi hormonal (Hormonal KB) memiliki risiko terkena kanker payudara. Pemeriksaan Payudara Sendiri (SADARI) adalah salah satu cara lebih mudah dan lebih efisien untuk dapat mendeteksi kelainan payudara sendiri. Tujuan penelitian ini untuk mengetahui pengaruh pendidikan kesehatan dengan metode demonstrasi dan media leaflet pada pemeriksaan payudara sendiri terhadap pengetahuan dan sikap akseptor $\mathrm{KB}$ hormonal WUS tentang SADARI. Desain penelitian ini adalah eksperimen semu dengan pemodelan desain pretestposttest. Populasi dibagi menjadi 3 kelompok, yaitu kelompok yang diberi pendidikan kesehatan dengan selebaran, metode demonstrasi, dan kombinasi dari selebaran + demonstrasi. Sampel dalam penelitian ini adalah akseptor KB KB suntik hormonal di lokasi
\end{abstract}


penelitian yang datang pada periode Juli - Oktober 2018 dengan teknik accidental sampling. Hasil penelitian menunjukkan bahwa pengetahuan dan sikap responden sebelum dan sesudah pendidikan kesehatan mengalami peningkatan yang signifikan dengan nilai $\mathrm{p}<0,05$ ( $\mathrm{p}=$ 0,000 ). Peningkatan skor nilai peringkat rata-rata pengetahuan secara statistik signifikan pada kelompok demonstrasi yang lebih baik daripada kelompok selebaran. Perbedaan nilai ratarata peringkat demonstrasi dan kelompok demonstrasi + selebaran tidak bermakna, sehingga dapat diartikan memiliki keunggulan yang sama.

Kata kunci: Kanker Payudara; Wanita usia subur; akseptor KB hormonal

\section{PRELIMINARY}

Cancer is the second largest cause of death in the world, data from the World Health Organization (WHO) has showed that cancer is the second leading cause of death in the world after cardiovascular disease. The number of cases of breast cancer was on the second ranked after cervical cancer which most suffered by women in the world. Data from the 2013 Basic Health Research (Riskesdas) showed that the prevalence of cancer and tumors was 1.4 per 1000 population. The highest cancer in Indonesia is breast cancer in women. (Ministry of Health, 2009), every 2 out of 10,000 women in the world are expected to experience breast cancer every year (Friskarini. K et al, 2016). Breast cancer is a disease with characterized by uncontrolled development of breast cells and tissue (Maharani, 2012. The cause of breast cancer is not yet known, it is estimated that many factors trigger cancer problems including genetics, environment and excessive levels of estrogen in the body. The growth of breast tissue has a sensitive reaction to the hormone estrogen, so women who are exposed to the hormone estrogen for a long time will have a greater risk of breast cancer (Harianto, 2005).

Wanita Usia Subur (WUS) or we could known as a fertile women who become a user of acceptors Hormonal contraception (Hormonal KB) has a risk of breast cancer because they had exposured to the hormone estrogen in contraception that has used for a long time, which is hormonal birth control is one of the triggers of breast cancer. Harianto's research results in 2005 stated that women using combination hormone birth control pills had a risk of 1,864 times higher breast cancer compared to non-combined birth control pills (Harianto, 2005). The prevalence of breast cancer patients in Indonesia is not yet known but based on estimates issued by Globocan, IARC in 2002 stated that the incidence of breast cancer in Indonesia was 26 per 100,000 women. The incidence of breast cancer in Indonesia increases at the age of 30 years and is highest in the age group 45-66 (Alhamsyah, 2009). 
Breast and cervical cancer is a major problem for women's health in Indonesia, and one of the contributing factors is the low coverage of early detection or cancer screening. (Ministry of Health, 2009). The Jakarta Breast Health Foundation conducted a survey in 2005 and stated that $80 \%$ of the people did not understand the importance of early breast screening (Ariestiani, 2010) The incidence of breast cancer in Indonesia is 21 new sufferers per 100,000 people (Kunta setiaji). Detection of breast cancer can be examined by yourself, $85 \%$ shows that a lump in the breast is found by the examinded of the patient it self. Suryaningsih (2009), states that Self Breast Examination (BSE) is one of the easier and more efficient ways to be able to detect breast abnormalities by yourself. Permenkes (2015) explains that the right time to check your own breasts is one week after menstruation is complete (on days 7 to 10 days after the first day of menstruation (Lubis UL, 2017)

The American Cancer Society recommends that every woman over the age of 20 could be able to do breast selfexamination every month, for ages $35-40$ years of mammography, and women over 40 years of age to check up with a specialist and over 50 years of age to do routine check-ups and mammography every year. Whereas women with high risk should be have more frequent and routine for breast examinations. WUS's awareness to conduct early detection of cancer examinations is very important, this awareness could be attempted by increasing WUS's knowledge and behavior about early detection of cancer examinations, especially breast cancer. Early detection of breast cancer can be done routinely by WUS at home. Health education is an activity that can increase knowledge and will influence a person's of their behavior (Ministry of Health, 2014). The results of Endang Zulaicha's 2012 study on WUS's knowledge and attitudes towards BSE showed that, $27.8 \%$ of WUS had less knowledge about breast cancer and $72.2 \%$ of WUS had less attitudes about BSE. This study describes a meaningful relationship between knowledge about breast cancer and attitudes towards BSE (Zulaicha E, 2012)

Research conducted by Aprilia et al in 2011 on the effect of health education with lecture and demonstration methods on knowledge of breast cancer and BSE skills has a significant influence on respondents' knowledge and skills. (Hidayati A et al, 2011). Health education with demonstrations will provide direct experience to the participants in doing a 
skill. Research conducted by Utari in 2012 at Yogyakarta has described about the skills of WUS's for doing the examination of SADARI, the research had shown the data that the WUS's whose not yet to have the counselling of the skills of doing a SADARI is more less of the skills for doing it, whereas for the WUS's who had the counselling of the examination of SADARI is about $93 \%$ that they are more have a skills for doing it. (Utari. S. 2012)

\section{METHODS}

This type of research was a quasiexperimental with a scheme of pretestposttest design. This study was used to find a causal relationship with the involvement of researchers in manipulating free variables (Nursalam 2011). This study uses a method that is by giving a pretest (initial observation) before giving an intervention, after being given an intervention, then posttest as the final observation (Hidayat 2007). The design of this study was to test the effectiveness of health education with demonstration methods and leaflet media on knowledge and awareness about WUS hormonal family planning acceptors. The population in the study was WUS hormonal family planning acceptor at BPM Ani Wahyu East Jakarta, part of the population to be studied or part of the number of characteristics possessed by the population (Hidayat, 2007). Sampling in this study was carried out by cluster sampling technique, namely grouping the samples taken in this study was WUS who became Hormonal KB acceptors. The sample size used in this study is in accordance with the Solvin Grand Formula of 40 respondents per group.

\section{RESULTS AND DISCUSSION}

Table 1. Differences in the Value of Average Ranking for Each Leaflet Group and Demonstration After Health Education

\begin{tabular}{lccc}
\hline \multicolumn{1}{c}{ Variable } & Leaflet & Demonstration & Score p \\
\hline Knowledge & & & \\
\hline Mean Rank & 26,50 & 38,50 & 0,007 \\
\hline Attitude & & & \\
\hline Mean Rank & 27,28 & 37,72 & 0,024 \\
\hline
\end{tabular}

Table 1 shows the results of the increase score in the average rating of the Leaflet group 26.50 and the Demonstration of 38.50 , the difference in the mean value of the rank 2 of the group has a significant difference that is with the value of $p=$ 0.007 (<0.05). The difference in the average attitude rating of the leaflet group 
is 27.28 and the demonstration is 37.72 with the value of $p=0.024$, so that it can be said that the difference in the average rating values of the two groups is very meaningful can arrange healthy menus. (Kurniawidjaja et al, 2013). The results of this study showed an increase in the average value of knowledge in the leaflet group of 2.95 points, demonstration of 4.46 points, and demonstration + leaflet of 5.47 points. The increase score in the average attitude value was leaflet group of 10.12 points, demonstration of 14.97 points, and demonstration + leaflet of 7.81 points. Based on the increase score in the average value of knowledge, the leaflet + demonstration group had a greater increase than the leaflet and demonstration group alone, but the highest increase score in the average attitude value occurred in the demonstration group alone, which was 14.97 points. This study provides health education about awareness with leaflet media and demonstration methods, based on the results it can be seen that health education with demonstration + leaflets is better than just giving leaflets or demonstrations, but changes in attitude are better in demonstration groups only.

Hardiningsih's research results on health education about HIV / AIDS in Surakarta stated that health education with leaflets was better in increasing respondents' knowledge and attitudes compared to lectures. Demonstration method is the simplest method compared to other teaching methods. The research on awareness by Siagian (2001) has states that the effectiveness of the success of training about awareness for young women at Dwija Dharma Boyolali Vocational School using the practical methods accompanied by lectures. Based on research conducted by Arini Estetia Putri, the lack of knowledge to SADARI is due to the lack of information media, in line with this research, according to Nina Munawaroh Damik, who stated that information about awareness has been widely publicized in various media, print and electronic media, so the limited information media cannot be used as an excuse of SADARI could not to be spread to the community. Lack of knowledge about SADARI will affect the behavior of respondents to do SADARI examination, in accordance with the results of the study of Dwi Sri Handayani (2008) which states that behavior in doing conscious is related to the level of knowledge and attitudes. Endang Zulaicha's research on the level of knowledge and attitudes toward awareness in women of childbearing age has stated that WUS's knowledge of awareness would influence her attitude. 
Table 2. Differences in Value of Average Ranking for Each Leaflet Group and Demonstration + Leaflets After Health Education

\begin{tabular}{lccc}
\hline \multicolumn{1}{c}{ Variabel } & Leaflet & Demonstration+Leaflet & Valeu p \\
\hline Knowledge & & & \\
\hline Mean Rank & 25,36 & 39,64 & 0,001 \\
\hline Attitude & & & \\
\hline Mean Rank & 25,72 & 39,28 & 0,003 \\
\hline
\end{tabular}

Table 2 shows the results of the increase score in the average rating of the Leaflet group 25.36 and Demonstration + leaflet 39.64 , the difference in the average value of the rank 2 of the group has a significant difference that is with the value $\mathrm{p}=0.001$ $(<0.05)$. The difference in the average attitude rating of the leaflet group is 25.72 and the demonstration is 39.28 with a value of $p=0.003$, soit can be said that the difference in the average rating of the two groups is very significant.

The results showed that the average demonstration group rank was higher than the leaflet group with a significant difference ie $p=0.007$ for knowledge and $p=0.024$ for attitudes, it showed us that the use of demonstration methods in health education was aware of WUS hormonal $\mathrm{KB}$ acceptors better than using leaflets. The results also showed that the average rating of knowledge and attitudes of the demonstration group + leaflet was higher than the leaflet group alone with $p=0.001$ for knowledge and $p=0.001$ for attitudes which meant that the difference was very significant.

The results of the comparison of demonstration groups with demonstration + leaflets were different but were not statistically significant because the value of $p>0.05$. These results can also be said that health education with demonstrations and demonstrations + leaflets has a good influence on WUS's knowledge and attitudes about SADARI examination, these effects are better than just leaflets. Demonstration methods are more suitable for teaching learning materials which are a movements of a process and things that are routine. Demonstrations are carried out for material that requires demonstrations or experiments. Martinis Yamin (2008) said: "The use of demonstration methods can be applied provided that they have the expertise to demonstrate the use of tools or carry out certain activities such as actual activities.Breast self-examination is an attempt to prevent breast cancer in the earlier stages of down staging (Manuaba, 
2010). The initial examination can be done by examining the breast itself and clinical examination carried out by trained health personnel can be done with a breast $\mathrm{x}$-ray photo mammography and ultrasound examination (Ministry of Health Pocket Book, 2009). Breast examination is useful to ensure that a person's breasts are still normal. if there are had an abnormalities such as infection, a tumor or cancer can be found earlier. breast cancer treated at an early stage may be recovered close to $95 \%$ (Cancer Pocket Book of the Ministry of Health, 2009). BSE is the easiest and cheapest way to find out a lump that is likely to develop into malignant cancer. (Yestiana Olfah et al, 2013)

Table 3. Differences in Rating Values for Each Demonstration

Group and Demonstration + Leaflets After Health Education

\begin{tabular}{lccc}
\hline \multicolumn{1}{c}{ Variable } & Demonstration & Demonstration+Leaflet & Score p \\
\hline Knowledge & & & \\
\hline Mean Rank & 31,72 & 33,28 & 0,711 \\
\hline Attitude & & & \\
\hline Mean Rank & 31,72 & 33,28 & 0,734 \\
\hline
\end{tabular}

In table 3 it can be seen that the difference in the average rating of knowledge in the demonstration and demonstration groups + leaflets has a $p$ value of 0.711 and attitude of 0.734 so that it does not have a statistically significant difference in value.This study did not examine the characteristics of respondents consisting of age, number of children owned, socioeconomic, duration of hormonal and other family planning use. Atania Rachma's research on the relationship between the duration of hormonal birth control and the incidence of breast cancer in Surakarta City states that the use of hormonal birth control that is more than 5 years old has 2,443 times the potential for breast cancer.

\section{CONCLUSION}

The level of knowledge and attitudes of WUS KB hormonal acceptors about the examination of early detection of breast cancer with BSE before and after health education with leaflet, demonstration, and leaflet + demonstration media had an increase in knowledge of 2.95 points, an increase in attitude of 10.12 points and was significant with $\mathrm{p}=0,000$. Health education about awareness on WUS hormonal family planning acceptors with demonstrations and demonstrations + 
leaflets was better than using leaflet media alone and statistically significant differences. This study only measures the level of knowledge and attitudes of respondents before and after the health education process, further research is expected to increase the influence of health education on the behavior of respondents.

\section{BIBLIOGRAPHY}

Lubis UL . 2017. Pengetahuan Remaja Putri Tentang Pemeriksaan Payudara Sendiri Dengan Perilaku sadari. Ilmu Kesehatan.2: 81-86.

Friskarini K, Manalu HSP. 2016. Implementation of Adolescent Friendly Health Services ( Afhs ) At Primary Health Care . Jakarta.

Dwi, S. 2016. Promosi kesehatan komprehensif. Jakarta.

Notoadmodjo. 2012. Perilaku kesehatan. Jakarta.

Tri, V. 2014. Sadari Sebagai Deteksi Dini Kanker Payudara Terhadap Pengetahuan Dan Sikap Remaja Putri Program Studi S-1 Keperawatan Stikes Kusuma Husada. Surakarta hal 72.

Fathria, Y. 2015. Pengembangan buku saku materi pemanasan global untuk SMP. Universitas Negeri Semarang,page 144

Departemen Kesehatan RI. 2009 . Buku Saku Kanker.pdf.

Defirna, IP. 2015. Gambaran Perilaku Pemeriksaan Payudara Sendiri
(Sadari) Pada Mahasiswi Fakultas Kedokteran Dan Ilmu Kesehatan UIN Syarif Hidayatullah. Jakarta

Kesehatan. K. 2014 Buku Pintar Posbindu PTM Penyakit Kanker. Jakarta.

Anindita Rachma Atania. 2015. Hubungan antara lama penggunaan $K B$ hormonal dan kejadian Kanker payudara di Kota Surakarta, Universitas Sebelas Maret Surakarta

Ekanita P, Khosidah A. 2013. Hubungan antara pengetahuan dan sikap WUS terhadap perilaku pemeriksaan payudara sendiri. Jurnal Ilmiah Kebidanan. 4(1): 167-177

Susilaningsih Zulaicha E, Suryani E. 2012. Tingkat pengetahuan dan sikap terhadap periksa payudara sendiri pada wanita usia produkstif. Prosiding seminar Nasional Stikes Aisyiyah Yogyakarta

Handayani SD. 2008. Hubungan antara tingkat pengetahuan dan sikap dengan perilaku para wanita dewasa awal dalam melakukan pemeriksaan payudara sendiri di Kelurahan Kalangan Kecamatan Pedan Klaten, PSIK FK UNDIP

Hardiningsih. 2011. Perbedaan pendidikan kesehatan dengan ceramah dan leaflet terhadap pengetahuan dan sikap dalam rangka pencegahan HIV/AIDS pada siswa kelas XI SMAN 4 Surakarta, STIKES Kusuma Husada Surakarta.

Kurniawidjaja M, dkk. 2013. Promosi pengetahuan, sikap, dan keterampilan hidup sehat pada kelompok senam. Jurnal Kesehatan Masyarakat Nasional. 7(9) 